\title{
Pre-weaning growth performance and carcass traits of Awassi and Chios-Awassi lambs
}

\author{
M.D. Obeidat ${ }^{1 \#}$, A.Y. Abdullah ${ }^{1}$, S. Kolib ${ }^{1}$, B.S. Obeidat ${ }^{1}$, K. Jawasreh ${ }^{1}$ \& H.S. Subih ${ }^{2}$ \\ ${ }^{1}$ Department of Animal Production, Faculty of Agriculture, Jordan University of Science and Technology, P.O.Box 3030, \\ Irbid 22110, Jordan \\ ${ }^{2}$ Department of Nutrition and Food Technology, Faculty of Agriculture, Jordan University of Science and Technology, \\ P.O. Box 3030, Irbid 22110, Jordan
}

(Received 19 July 2018; Accepted 21 November 2018; First published online 12 March 2019)

\author{
Copyright resides with the authors in terms of the Creative Commons Attribution 4.0 South African Licence. \\ See: http://creativecommons.org/licenses/by/4.0/za \\ Condition of use: The user may copy, distribute, transmit and adapt the work, but must recognise the authors and
}

the South African Journal of Animal Science.

\begin{abstract}
One hundred and three lambs (26 Chios-Awassi (CA) and 77 Awassi (AA)) were used to evaluate the effect of crossbreeding on growth performance, body dimensions and carcass characteristics. At weaning, $8 \mathrm{CA}$ and $8 \mathrm{AA}$ male lambs were randomly selected to examine carcass traits. Crossbred CA lambs were heavier at birth than their AA counterparts, while average daily gain (ADG) and weaning weights were not affected by genotype. CA lamb genotype had greater diagonal body length, hip height and heart girth than AA lambs. Hot and cold carcass weight, dressing percentage, body length, leg length, maximum shoulder width, and width behind shoulder were greater in CA lambs compared with AA lambs. AA lambs had significantly heavier fat tail and leg cut weights, while shoulder cut weights were heavier in the CA lambs. CA lambs had greater rib fat depth and tissue depth thickness than AA lambs. Longissimus muscle area was significantly greater in CA than in AA lambs. In conclusion, CA lambs had greater birth weights, body dimensions and dressing percentage than AA lambs. Additionally, aside from the tail and leg cuts, carcass components were heavier in CA crossbred lambs.
\end{abstract}

Keywords: Carcass characteristics; crossbreeding; weaning weight

\# Corresponding author: mdobeidat@just.edu.jo

\section{Introduction}

The aim of genetic programmes is to improve traits of economic importance, while minimizing the production costs (Kosgey \& Okeyo, 2007). In the sheep industry, pre- and post-weaning lamb growth traits are considered important. Several methods and technologies are used to improve lamb traits and growth rate, one of which is crossbreeding. Crossbreeding is usually used to improve carcass and low heritability (such as fertility traits). It can improve traits without the need for advanced and costly technologies (Nitter, 2000). However, crossbred animals are sold at cheaper prices than purebred ones owing to consumer preferences.

The sheep population in Jordan is around 2.5 million head, supplying about $47 \%$ of total meat production in the country. In developing countries such as Jordan, sheep and goats play a major role in household economics through meat and milk production (Steinfeld et al., 2006). The growing demand for red meat owing to the increasing population makes it a necessity for Jordan to start up a genetic improvement programme to help in meeting the country's market requirements. However, one must keep in mind that consumers in Jordan prefer carcasses with certain phenotypic traits, such as the presence of a fat tail. Therefore, any crossbreeding programme should take this into consideration. Maintaining the fat tail can be accomplished by producing the first generation or backcrossing the first generation with Awassi (Rosov \& Gootwine, 2013). However, backcrossed animals usually lose some levels of heterosis (Abdullah et al., 2010) and, as a result, have reduced performance compared with first-generation animals. To avoid the need to create backcrossed animals, the choice of breed to be crossed with Awassi is of great importance. Because of these issues, the authors' hypothesis was that using the Chios as a semi-fat-tail sheep breed to 
be crossbred with Awassi would produce fat-tailed lambs. The objectives of this study were to evaluate the effects of crossbreeding on birth weight, weaning weight and pre-weaning growth traits as well as carcass traits at weaning.

\section{Materials and Methods}

All procedures were approved by the Institutional Animal Care and Use Committee of Jordan University of Science and Technology (JUST). The study was conducted at the Agricultural Research and Training Unit at JUST from June 2014 to February 2015. One hundred and sixty homogenized Awassi ewes were divided into two groups: 100 ewes to produce pure Awassi lambs and 60 ewes to be bred to Chios rams. The occurrence of oestrus of the ewes were synchronized using intravaginal progesterone sponges (FGA) (Ceva, Santa Animals, Libourne, France) to ensure lambing uniformity. For Chios rams, mating was done with assisted hand mating. Ultrasonography performed 45 days post mating revealed that only $80 \%$ of the Awassi-mated and $50 \%$ of the Chios-mated ewes were pregnant. Single-born lambs were ear tagged and weighed, and data were recorded. Ewes with their lambs were fed a lactation diet until weaning. Of all lambs, 103 (77 AA and $26 \mathrm{CA}$ ) were weaned at 65 days old, at which time fasting bodyweights and body measurements were recorded. Body dimension measurements were recorded using a plastic tape and large callipers, namely diagonal body length (DBL), wither height $(\mathrm{WH})$, hip height $(\mathrm{HH})$, body circumference (BC), width behind the shoulders (WBS) and rump height $(\mathrm{RH})$.

Eight ram lambs from each genetic group were slaughtered at weaning following 12 hours of fasting. Live bodyweight was recorded before slaughtering. Lambs were slaughtered and carcasses were dressed as described by Abdullah et al. (2010). Hot carcass weight was recorded the carcass was washed with fresh water. Carcasses were chilled for 24 hours at $4{ }^{\circ} \mathrm{C}$, and then weighed to obtain the cold weights. Fat tails were separated (from the area around the hind legs of the carcass) and weighed. Carcass length (CL), leg length (LL), carcass maximum shoulder width (CMSW), and carcass width behind the shoulder (CWBS) were recorded on hanging carcasses using a metal metre and large callipers. Each carcass was then cut into four parts (leg, shoulder, lion and rack) following the procedure described by Abdullah et al. (2010). Each cut was weighed and then the depth of tissue over the surface of rib at point $110 \mathrm{~mm}$ from the midline and area of $M$. longissimus (GR), depth of subcutaneous fat over the M. obliquus externus abdomini (J), fat thickness over the ventral edge of $M$. gluteus medius (L3), the depth of subcutaneous fat over the $M$. latissius dorsi at a point at the right angles to the midline (S2), area of M. Longissimus (LMA), M. longissimus width (A), M. longissimus depth (B), and fat depth (C) was recorded. The right leg cut was then sealed into plastic bags and frozen at $-20^{\circ} \mathrm{C}$ until dissected.

Before dissection, legs were thawed in coolers at $4{ }^{\circ} \mathrm{C}$ in plastic bags. The leg was dissected, and subcutaneous fat, intermuscular fat, muscle, bone and scrap were separated and weighed. Four muscles from the right leg were examined. Those included $M$. semitendinosus, M. quadriceps, M. semimembranosus and $M$. biceps femoris.

Data were analysed using PROC mixed procedures of SAS (SAS Inst. Inc. Cary, NC). Lamb birth and weaning weights, pre-weaning average daily gain, and linear body measurements were analysed using mixed linear models. Fixed effects that were investigated, included lamb genotype, lamb sex and their interactions. Dam identification was modelled as a random effect as shown in the mathematical equation below.

$$
\mathrm{Y}_{\mathrm{ijk}}=\mu+\mathrm{G}_{\mathrm{i}}+\mathrm{S}_{\mathrm{j}}+(\mathrm{GS})_{\mathrm{ij}}+\varepsilon_{\mathrm{ijk}}
$$

where: $\mathrm{Y}_{\mathrm{ijk}}$ the dependent variable

$\mu$ is the overall mean

$G_{i}$ is the genotype effect, where $i=A A$ or $C A$

$S_{j}$ is the sex effect, where $\mathrm{j}=$ male or female

$(\mathrm{GS})_{\mathrm{ij}}$ is the interaction between the two effects

$\varepsilon_{\mathrm{ijk}}$ is the random error

Carcass traits and meat quality were analysed using the generalized linear model of SAS, in which genotype was treated as the main effect. Carcass weight was included as covariate for weight analysis of cuts.

$Y_{i j}=\mu+G_{i}+\varepsilon_{i j}$

where: $\mathrm{Y}_{\mathrm{ij}}$ is the dependent variable 
$\mu$ is the overall mean

$\mathrm{G}_{\mathrm{i}}$ is the genotype effect, where $\mathrm{i}=\mathrm{AA}$ or $\mathrm{CA}$

$\varepsilon_{\mathrm{ij}}$ is the random error

Mean separation for all traits was performed using Tukey-Kramer test and significance level was determined at $(P<0.05)$.

\section{Results and Discussion}

Lamb sex had a highly significant effect on birth weight, weaning weight and pre-weaning ADG (Table 1). Male lambs were heavier at birth and weaning and gained more compared with female lambs, which is consistent with a previous study (Gardner et al., 2007). CA lambs were heavier $(P<0.01)$ at birth than AA lambs. These results agree with Emsen (2005), who reported that crossbred Awassi lambs tend to be heavier at birth than their purebred counterparts. Similarly, Gavojdian et al. (2013) reported that crossbred Morkaraman/Romanov lambs were heavier at birth than their purebred counterparts. On the other hand, Korkmaz \& Emsen (2016) reported that crossbreeding did not affect lamb birth weight. In the current study, lamb genotype did not affect weaning weight and pre-weaning average daily gain (ADG). These results agree with Abdullah \& Tabbaa (2011), who found that weaning weight for $F_{1}$ Chios-Awassi lambs did not differ from purebred Awassi lambs. However, Mellado et al. (2016) reported that crossbred Dorper-Turcana lambs were heavier at weaning than the purebred Turcana lambs.

Table 1 Least squares means and standard error for preweaning growth performance of Awassi and ChiosAwassi lambs

\begin{tabular}{lcccc}
\hline \multirow{2}{*}{ Trait } & \multicolumn{2}{c}{ Male } & \multicolumn{2}{c}{ Female } \\
\cline { 2 - 5 } & Awassi & Chios-Awassi & Awassi & Chios-Awassi \\
\hline BWT $(\mathrm{kg})$ & $4.52^{\mathrm{b}, \mathrm{x}} \pm 0.081$ & $5.55^{\mathrm{a}, \mathrm{x}} \pm 0.16$ & $3.89^{\mathrm{b}, \mathrm{y}} \pm 0.11$ & $4.73^{\mathrm{a}, \mathrm{y}} \pm 0.15$ \\
WWT $(\mathrm{kg})$ & $18.33^{\mathrm{x}} \pm 0.24$ & $18.86^{\mathrm{x}} \pm 0.45$ & $16.55^{\mathrm{y}} \pm 0.29$ & $17.86^{\mathrm{y}} \pm 0.42$ \\
ADG $(\mathrm{kg})$ & $0.23^{\mathrm{x}} \pm 0.03$ & $0.24^{\mathrm{x}} \pm 0.01$ & $0.21^{\mathrm{y}} \pm 0.05$ & $0.21^{\mathrm{y}} \pm 0.06$ \\
& & & & \\
\hline
\end{tabular}

${ }^{a, b}$ Means with different superscripts with the same row and the same sex group differ $(P<0.05)$

${ }^{x, y}$ Means with different superscripts with the same row and the same genetic group differ $(P<0.05)$

BWT: birth weigh

WWT: weaning weigh

ADG: pre-weaning average daily gain

Birth weight is related directly to the genetics and nutrition of the pregnant ewe. Most genetic factors that affect birth weight are related to maternal and paternal genes. The additive effect of the Chios breed may have affected the birth weight results. On the other hand, weaning weight is greatly influenced by the dam's milk yield. Since the dams in this study were all from the Awassi breed, it was expected that weaning weight and pre-weaning ADG would not differ between cross and purebred lambs.

Awassi male lambs had greater body length, wither height, width behind the shoulders, heart girth, rump height and hip height compared with female lambs, while no sex effect appeared for the Chios-Awassi lambs for the same traits (Table 2). Genotype of lambs had a significant effect on diagonal body length, hip height and heart girth, while it did not affect $(P>0.05)$ rump height, wither weight and width behind the shoulders. In general, $F_{1}$ CA male lambs had numerically greater body dimensions than the purebred male Awassi lambs. Chios-Awassi female lambs had greater $(P<0.01)$ diagonal body length, heart girth, rump height, hip height, wither height and width behind the shoulders than AA female lambs. These results agree with Zamfir et al. (2012), who reported that crossbred female lambs had higher values for the same traits in question when compared with the purebred lambs. Contrary to this, Koritiaki et al. (2013) found no significant effect between purebred and first-generation crossbred lambs for heart girth and body length at weaning. The superiority of male lambs in body dimension in this study is expected to be due to the influence of the Y-chromosome, which has specific effects on body weight and linear body dimension (Kashan et al., 2005). The effect of sire breed on body dimensions was previously reported by Al-Tarayrah \& Tabbaa (1999). 
Table 2 Least squares means and standard error for body dimensions in Awassi and Chios-Awassi lambs

\begin{tabular}{lcccc}
\hline & \multicolumn{2}{c}{ Male } & \multicolumn{2}{c}{ Female } \\
\cline { 2 - 5 } & Awassi & Chios-Awassi & Awassi & Chios-Awassi \\
\hline DBL (cm) & $56.59^{\mathrm{x}} \pm 1.10$ & $58.44 \pm 1.71$ & $49.53^{\mathrm{b}, \mathrm{y}} \pm 1.26$ & $56.96^{\mathrm{a}} \pm 1.66$ \\
WH (cm) & $59.23^{\mathrm{x}} \pm 1.32$ & $58.79 \pm 1.87$ & $53.84^{\mathrm{b}, \mathrm{y}} \pm 1.49$ & $58.86^{\mathrm{a}} \pm 1.78$ \\
WBS (cm) & $20.33^{\mathrm{x}} \pm 0.68$ & $18.77 \pm 0.98$ & $16.61^{\mathrm{b}, \mathrm{y}} \pm 0.77$ & $18.74^{\mathrm{a}} \pm 0.92$ \\
HG (cm) & $65.43^{\mathrm{x}} \pm 0.97$ & $66.55 \pm 1.53$ & $60.06^{\mathrm{b}, \mathrm{y}} \pm 1.14$ & $65.09^{\mathrm{a}} \pm 1.45$ \\
$\mathrm{RH}(\mathrm{cm})$ & $61.94^{\mathrm{x}} \pm 0.91$ & $60.37 \pm 1.41$ & $55.70^{\mathrm{b}, \mathrm{y}} \pm 1.06$ & $59.11^{\mathrm{a}} \pm 1.32$ \\
$\mathrm{HH}(\mathrm{cm})$ & $61.14^{\mathrm{x}} \pm 1.14$ & $61.12 \pm 1.67$ & $54.99^{\mathrm{b}, \mathrm{y}} \pm 1.30$ & $60.26^{\mathrm{a}} \pm 1.59$ \\
\hline
\end{tabular}

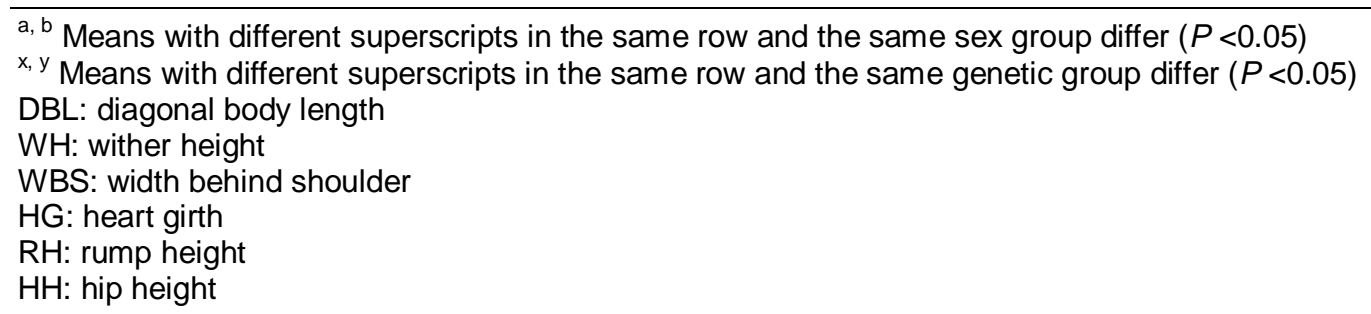

Chios-Awassi lambs had higher $(P<0.01)$ hot and cold carcass weights, dressing percentage and carcass linear measurements compared with the straight-bred Awassi lambs (Table 3 ). These results agree with a previous study (Teklebrhan et al., 2014). Since carcass traits are moderately to highly heritable (Waldron et al., 1992), these results were expected.

Table 3 Least squares means and standard error for carcass linear measurements for Awassi and ChiosAwassi lambs

\begin{tabular}{lcc}
\hline \multirow{2}{*}{ Trait } & \multicolumn{2}{c}{ Breed } \\
\cline { 2 - 3 } & Awassi & Chios-Awassi \\
\hline HCW $(\mathrm{kg})$ & $8.48^{\mathrm{b}} \pm 0.45$ & $9.18^{\mathrm{a}} \pm 0.46$ \\
CCW $(\mathrm{kg})$ & $8.4^{\mathrm{b}} \pm 0.45$ & $9.1^{\mathrm{a}} \pm 0.45$ \\
DP\% & $44^{\mathrm{b}} \pm 0.01$ & $47^{\mathrm{a}} \pm 0.01$ \\
CL (cm) & $86.8^{\mathrm{b}} \pm 1.69$ & $95.6^{\mathrm{a}} \pm 1.74$ \\
LL (cm) & $17.89^{\mathrm{b}} \pm 0.44$ & $21.75^{\mathrm{a}} \pm 0.44$ \\
CMSW (cm) & $12.13^{\mathrm{b}} \pm 0.46$ & $14.98^{\mathrm{a}} \pm 0.46$ \\
CWBS (cm) & $11.25^{\mathrm{b}} \pm 0.36$ & $13.37^{\mathrm{a}} \pm 0.36$ \\
\hline
\end{tabular}

\footnotetext{
a,b means with different superscripts with the same row differ $(P<0.05)$

HCW: hot carcass weight;

CCW: cold carcass weight;

DP: dressing percentage;

CL: carcass length;

LL: leg length;

CMSW: carcass maximum shoulder width;

CWBS: carcass width behind the shoulder
}

The genotype of the lamb had a significant effect on shoulder, fat tail and leg weights, while it did not affect $(P>0.05)$ rack and loin weights (Table 4). Shoulder and leg weights were heavier $(P<0.05)$ for CA lambs than for AA lambs, while fat tail weights were lower $(P<0.05)$. These results agree with Moreno et al. (2001), who found that fat tail weights for $F_{1}$ Zel-Chaal were lower $(P<0.05)$ than in purebred Chaal lamb. 
Chios-Awassi lambs did not differ $(P>0.05)$ from AA lambs in rack and loin weights. These results agree with Ružić-Muslić et al. (2012), who found no difference $(P>0.05)$ in rack and loin weights among two crossing $\mathrm{F}_{1}$ Pramenka-Württemberg and three crossing $F_{1}$ Pramenka-Württemberg-lle de France.

Table 4 Least squares means and standard error for carcass cuts in Awassi and Chios-Awassi lambs

\begin{tabular}{lcc}
\hline \multirow{2}{*}{ Trait } & \multicolumn{2}{c}{ Genetic group } \\
\cline { 2 - 3 } & Awassi & Chios-Awassi \\
\hline Shoulder $(\mathrm{kg})$ & $3.34^{\mathrm{b}} \pm 0.14$ & $3.72^{\mathrm{a}} \pm 0.15$ \\
Rack $(\mathrm{kg})$ & $0.58 \pm 0.07$ & $0.66 \pm 0.07$ \\
Loin $(\mathrm{kg})$ & $0.66 \pm 0.05$ & $0.8 \pm 0.05$ \\
Legs $(\mathrm{kg})$ & $2.98^{\mathrm{b}} \pm 0.19$ & $2.72^{\mathrm{a}} \pm 0.19$ \\
Fat tail $(\mathrm{kg})$ & $0.41^{\mathrm{a}} \pm 0.05$ & $0.25^{\mathrm{b}} \pm 0.05$ \\
\hline
\end{tabular}

${ }^{\mathrm{a}, \mathrm{b}}$ Means with different superscripts with the same row differ $(P<0.05)$

The genotype of the lambs had a significant effect on the depth of subcutaneous fat over the $M$. obliquus externus abdomini (J), the depth of tissue over the surface of rib at point $110 \mathrm{~mm}$ from the midline and area of $M$. longissimus (GR). However, lamb genotype did not affect $(P>0.05)$ the depth of subcutaneous fat over the $M$. latissius dorsi at a point at the right angles to the midline (S2), fat thickness over the ventral edge of $M$. gluteus medius (L3), muscle weight (EMW), M. longissimus width (A), and $M$. longissimus depth (B). Table 5 shows least squares means and SE for fat thickness and $M$. longissimus measurements of $\mathrm{AA}$ and $\mathrm{CA}$ lambs. J and GR were greater $(P<0.05)$ in $\mathrm{F}_{1} \mathrm{CA}$ than in AA lambs. These results agree with Cloete et al. (2007). Neither S2 nor L3 differed $(P>0.05)$ between genotypes, which agrees with Kashan et al. (2005), who reported that S2 and L3 for $F_{1}$ Suffolk-Merino did not differ from purebred Merino lambs.

Table 5 Least squares means and standard error for fat thickness and $M$. longissimus measurements of Awassi and Chios-Awassi lambs

\begin{tabular}{lcc}
\hline \multirow{2}{*}{ Trait } & \multicolumn{2}{c}{ Genetic group } \\
\cline { 2 - 3 } & Awassi & Chios-Awassi \\
\hline L3 $(\mathrm{mm})$ & $1.78 \pm 0.28$ & $1.63 \pm 0.28$ \\
S $(\mathrm{mm})$ & $1.11 \pm 0.18$ & $1.16 \pm 0.19$ \\
$\mathrm{~J}(\mathrm{~mm})$ & $1.35^{\mathrm{b}} \pm 0.31$ & $2.44^{\mathrm{a}} \pm 0.32$ \\
GR $(\mathrm{mm})$ & $8.2^{\mathrm{b}} \pm 0.43$ & $10.9^{\mathrm{a}} \pm 0.43$ \\
A $(\mathrm{mm})$ & $53.7 \pm 0.94$ & $53.13 \pm 0.94$ \\
B $(\mathrm{mm})$ & $19.13 \pm 1.13$ & $18.4 \pm 1.13$ \\
LMA $\left(\mathrm{cm}^{2}\right)$ & $9.0^{\mathrm{b}} \pm 0.09$ & $9.3^{\mathrm{a}} \pm 0.10$ \\
EMW $(\mathrm{g})$ & $73.8 \pm 3.84$ & $70.9 \pm 3.84$ \\
\hline
\end{tabular}

\footnotetext{
a, b Means with different superscripts with the same row differ $(P<0.05)$

L3: fat thickness over the ventral edge of $M$. gluteus medius

S2: depth of subcutaneous fat over the $M$. latissimus dorsi at a point at right angles to the midline

$\mathrm{J}$ : the depth of subcutaneous fat over the M. obliquus externus abdominis

GR: depth of tissue over the surface of rib at point $110 \mathrm{~mm}$ from the midline

A: $M$. longissimus width

B: $M$. longissimus depth

LMA: area of $M$. longissimus

EMW: eye muscle weight
} 
The area of $M$. longissimus was higher $(P<0.05)$ in CA than in AA lambs. These results agree with those of Ružic-Muslic et al. (2012), who found that the area of $M$. longissimus was greater in $F_{1}$ Poll DorsetBorder Leicester Merino than in purebred Merino lambs. CA lambs did not differ $(P>0.05)$ from AA lambs at eye muscle weight, $M$. longissimus width, and $M$. longissimus depth. Similar results were reported by Teklebrhan et al. (2014), who found that eye muscle weight, $M$. longissimus thoracis depth and $M$. longissimus thoracis width did not differ for $F_{1}$ lle de France-Merino Branco from purebred Merino Branco lambs.

Least squares means and standard error (SE) for dissected leg cut components in AA and CA lambs are presented in Table 6. Lamb genotype did not affect subcutaneous fat weight, intermuscular fat weight, total muscle weight, total bone weight, $M$. semitendinosus, $M$. semimembranosus and $M$. quadriceps, but had a significant effect on biceps femoris muscle weight. Chios-Awassi lambs had similar subcutaneous fat weight, intermuscular fat weight, total muscle weight and total bone weight to AA lambs. These results agree with those of Gardner et al. (2007), who found that crossbred Awassi lambs did not differ from Awassi lambs for the same traits. In the present study, the lack of difference in three of the leg muscles agrees with Scales et al. (2000), who found that semimembranosus, semitendinosus and quadriceps muscle weight was not affected by crossbreeding in Romney lambs. Chios-Awassi lambs had heavier $(P<0.01)$ biceps femoris muscle weight than the AA lambs. Similar results were reported by Scales et al. (2000), who found the biceps femoris muscle weight was heavier in $F_{1}$ East Friesian (Finn-Texel) than in purebred Romney lambs.

Table 6 Least squares means and standard error for dissected leg cut weight in Awassi and Chios-Awassi lambs

\begin{tabular}{lcc}
\hline \multirow{2}{*}{ Item } & \multicolumn{2}{c}{ Genetic group } \\
\cline { 2 - 3 } & Awassi & Chios-Awassi \\
\hline Semitendinosus muscle weight (g) & $51.74 \pm 2.91$ & $43.62 \pm 3.01$ \\
Semimembranosus muscle weight (g) & $109.6 \pm 6.11$ & $94.34 \pm 6.29$ \\
Biceps femoris muscle weight (g) & $119.7^{\mathrm{b}} \pm 5.47$ & $101.1^{\mathrm{a}} \pm 5.55$ \\
Quadriceps muscle weight (g) & $196.5 \pm 14.98$ & $138.6 \pm 15.43$ \\
Subcutaneous fat weight (g) & $91.25 \pm 15.90$ & $85.12 \pm 16.12$ \\
Intermuscular fat weight (g) & $38.7 \pm 1.35$ & $37.0 \pm 1.37$ \\
Total muscle weight (g) & $912.06 \pm 43.1$ & $875.7 \pm 44.16$ \\
Total bone weight (g) & $405.9 \pm 13.94$ & $440.6 \pm 14.33$ \\
\end{tabular}

$\overline{\mathrm{a}, \mathrm{b}}$ Means with different superscripts within the same row differ $(P<0.05)$

\section{Conclusion}

In conclusion, using Chios rams as sires had a positive effect on lamb birth weight without affecting weaning weight and pre-weaning ADG. Reciprocal crosses may be created to improve these traits because of the higher milk production in the Chios breed ewes. Finally, aside from leg and tail weights, crossbreeding Awassi with Chios improved some carcass traits at weaning.

\section{Acknowledgments}

The authors wish to thank the Deanship of Scientific Research at Jordan University of Science and Technology for the financial support of this project (113/2014). Appreciation is expressed to the farm staff at the Agricultural Research and Training Unit at Jordan University of Science and Technology. Authors are also grateful to Rami Kridli, Majdi Abu Shmais and Rolan AL-Shareef for their technical support.

\section{Authors' Contributions}

M.D.O: Designing, supervising and writing the manuscript, A.Y.A.: Helping in statistical analysis and manuscript writing, S.K.: Drafting the manuscript, B.S.O.: Helping in technical writing, K.J.: Drafting the manuscript, H.S.S.: Drafting the manuscript.

\section{Conflict of Interest}

The authors declare that there are no conflicts of interests. 


\section{References}

Abdullah, A.Y., Kridli, R.T., Shaker, M.M. \& Obeidat, M.D., 2010. Investigation of growth and carcass characteristics of pure and crossbred Awassi lambs. Small Rumin. Res. 94, 167-175.

Abdullah, B.M. \& Tabbaa, M.J., 2011. Comparison of body weight and dimensions at birth and weaning among Awassi and Chios sheep breeds and their crosses. Jordan J. Agr. Sci. 7, 656-666.

Al-Tarayrah, J.A. \& Tabbaa, M.J., 1999. Some factors affecting body weight and dimensions and its adjustment factors for Awassi lambs in Jordan. Dirasat Agr. Sci. 26, 168-178.

Cloete, J., Cloete, S., Olivier, J. \& Hoffman, L., 2007. Terminal crossbreeding of Dorper ewes to lle de France, Merino Landsheep and SA Mutton Merino sires: Ewe production and lamb performance. Small Rumin. Res. 69, 28-35.

Emsen, E., 2005. Testicular development and body weight gain from birth to 1 year of age of Awassi and Redkaraman sheep and their reciprocal crosses. Small Rumin. Res. 59, 79-82.

Gardner, D., Buttery, P., Daniel, Z. \& Symonds, M., 2007. Factors affecting birth weight in sheep: Maternal environment. Reprod. 133, 297-307.

Gavojdian, D., Cziszter, L.T., Pacala, N. \& Sauer, M., 2013. Productive and reproductive performance of Dorper and its crossbreds under a Romanian semi-intensive management system. S. Afr. J. Anim. Sci. 43, 219-228.

Kashan, N., Azar, G.M.A., Fzalzadeh, A. \& Salehi, A., 2005. Growth performance and carcass quality of fattening lambs from fat-tailed and tailed sheep breeds. Small Rumin. Res. 60, 267-271.

Koritiaki, N.A., Ribeiro, E.L.deA., Mizubuti, I.Y., Silva, Ldas.D.F., Barbosa, M.A.A.deF., Muniz, D.C., Scerbo, C. \& Fernandes, deS.D,F., 2013. Effect of environmental factors on performance of purebred and crossbred Santa Inês lambs from birth to 154 days of age. R. Bras. Zootec. 42, 87-94.

Korkmaz, M.K. \& Emsen, E., 2016. Growth and reproductive traits of purebred and crossbred Romanov lambs in Eastern Anatolia. Anim. Reprod. 13, 3-6.

Kosgey, I. \& Okeyo, A., 2007. Genetic improvement of small ruminants in low-input, smallholder production system, Technical and infrastructural issues. Small Rumin. Res. 70, 76-88.

Mellado, M., Macías, U., Avendaño, L., Mellado, J. \& García, J.E., 2016. Growth and pre-weaning mortality of Katahdin lamb crosses. Rev. Colomb. Cienc. Pecu. 29, 288-295.

Moreno, C., Bouix, J., Brunel, J., Weisbecker, J., François, D. \& Lantier, F., 2001. Genetic parameter estimates for carcass traits in the inra401 composite sheep strain. Livest. Prod. Sci. 69, 227-232.

Nitter, G., 2000. Developing crossbreeding structures for extensive grazing systems, utilising only indigenous animal genetic resources. Developing breeding strategies for lower input. Anim. Prod. Environ. 179.

Rosov, A., \& Gootwine, E., 2013. Birth weight, and pre-and postweaning growth rates of lambs belonging to the AfecAssaf strain and its crosses with the American Suffolk. Small Rumin. Res. 113, 58-61.

Ruži-Musli, D.,Petrovi, M., Bijeli, Z., Panteli, V. \& Periši, P., 2012. The effect of crossing on meat yield and quality of weaned lambs. Biotechnol. Anim. Husb. 28, 751-758.

Scales, G., Bray, A., Baird, D., O'Connell, D. \& Knight, T., 2000. Effect of sire breed on growth, carcass, and wool characteristics of lambs born to Merino ewes in New Zealand. NZ. J. Agr. Res. 43, 93-100.

Steinfeld, H., Wassenaar, T. \& Jutzi, S., 2006. Livestock production systems in developing countries: status, drivers, trends. Rev. Sci. Technol. 25, 505-516.

Teklebrhan, T., Urge, M., Mekasha, Y. \& Baissa, M., 2014. Pre-weaning growth performance of crossbred lambs (Dorper $x$ indigenous sheep breeds) under semi-intensive management in eastern Ethiopia. Trop. Anim. health Prod. 46, 455-460.

Waldron, D., Clarke, J., Rae, A., Kirton, A. \& Bennett, G., 1992. Genetic and phenotypic parameter estimates for selection to improve lamb carcass traits. NZ. J. Agr. Res. 35, 287-298.

Zamfir, C.Z., Vicovan, G., Radu, R., Rău, V. \& Pivoda, C.A., 2012. Morph-productive characters of the precursors of the new Romanian sheep breeds for the meat production. Lucrări Ştiinţifice-Universitatea de Ştiinţe Agricole şi Medicină Veterinară, Seria Zootehnie. 58, 97-103. 